Historic, Archive Document

Do not assume content reflects current scientific knowledge, policies, or practices. 



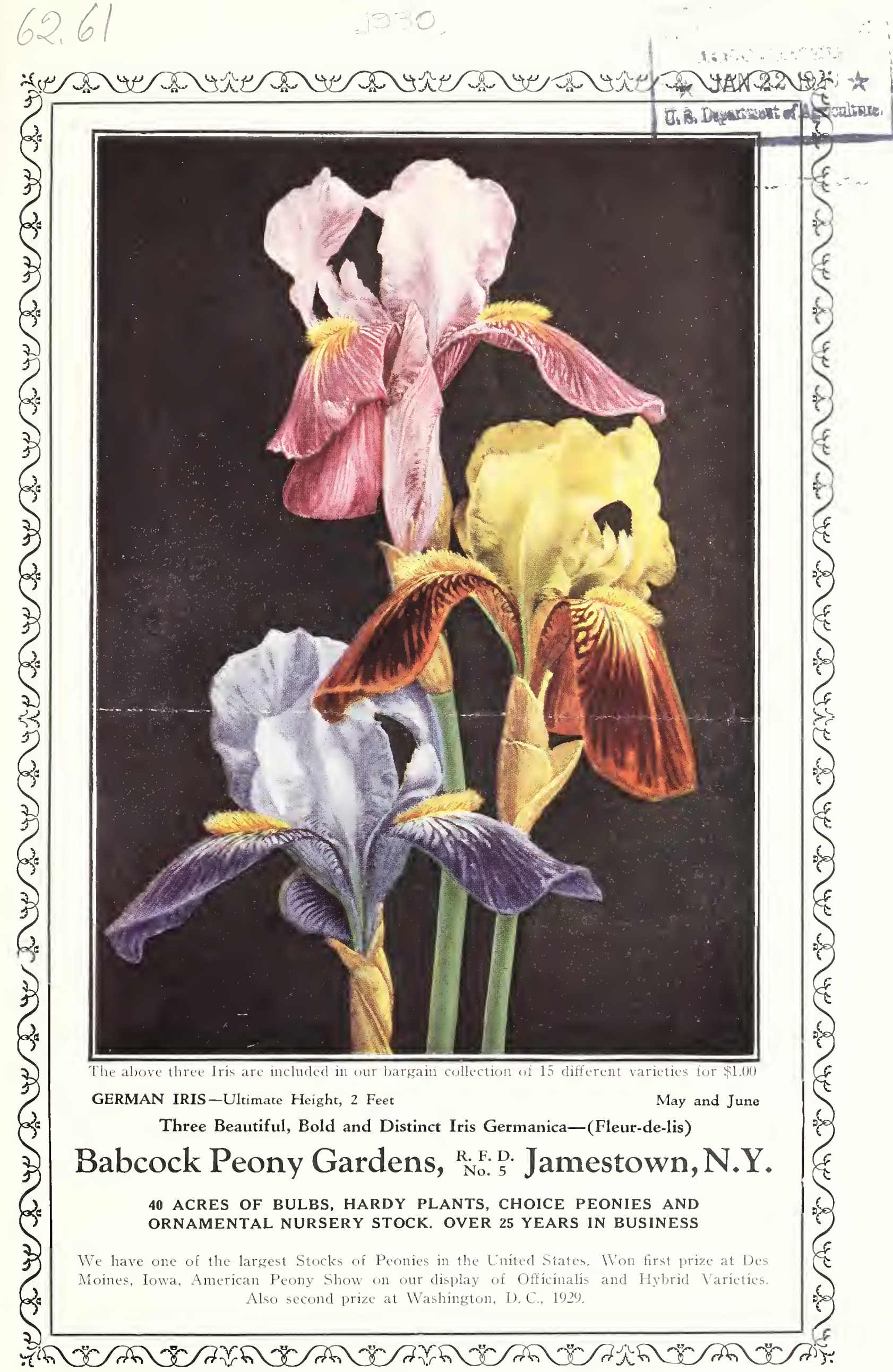





\section{Special Offer of Popular Perennials for All Summer Bloom}
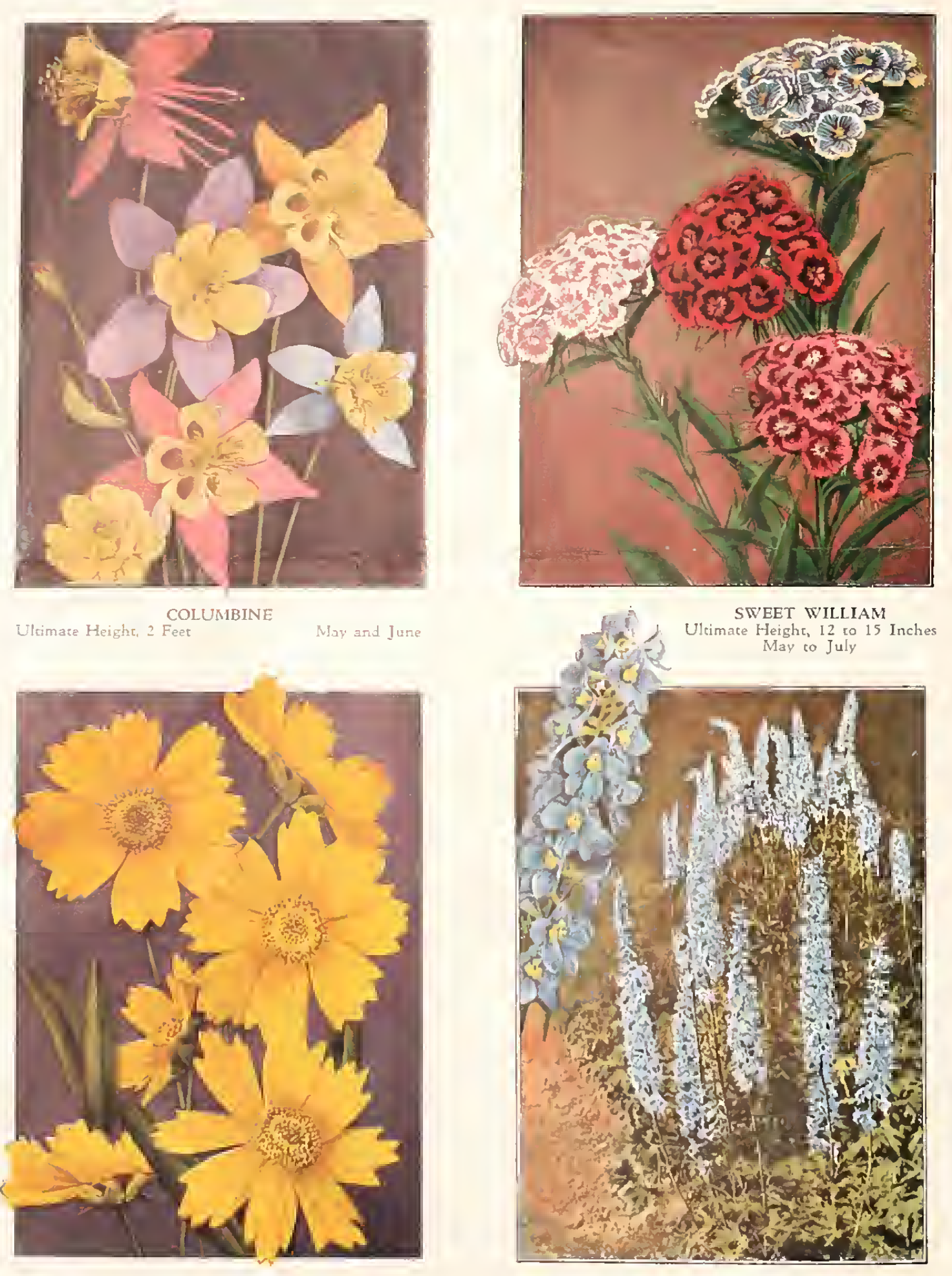
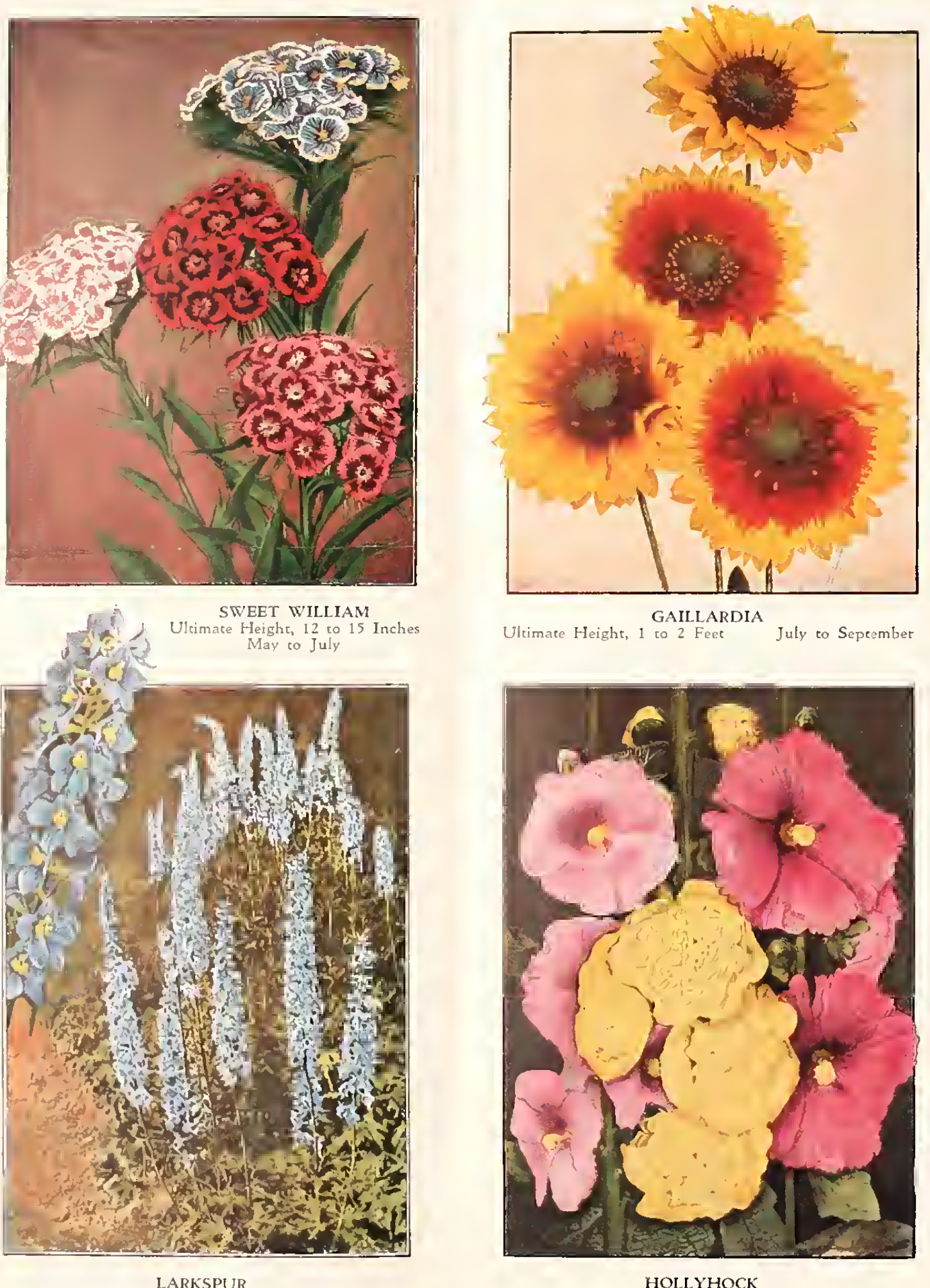
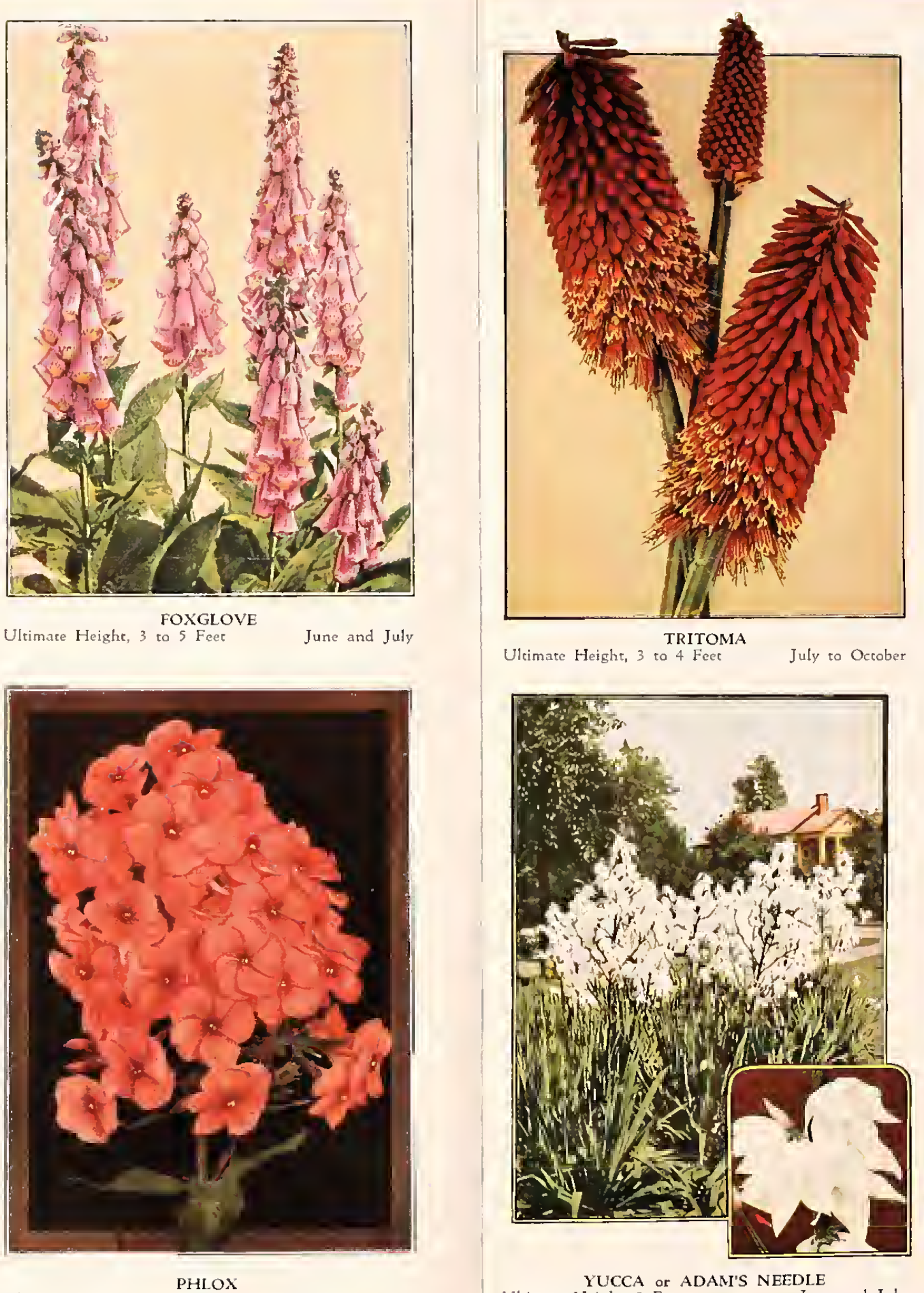
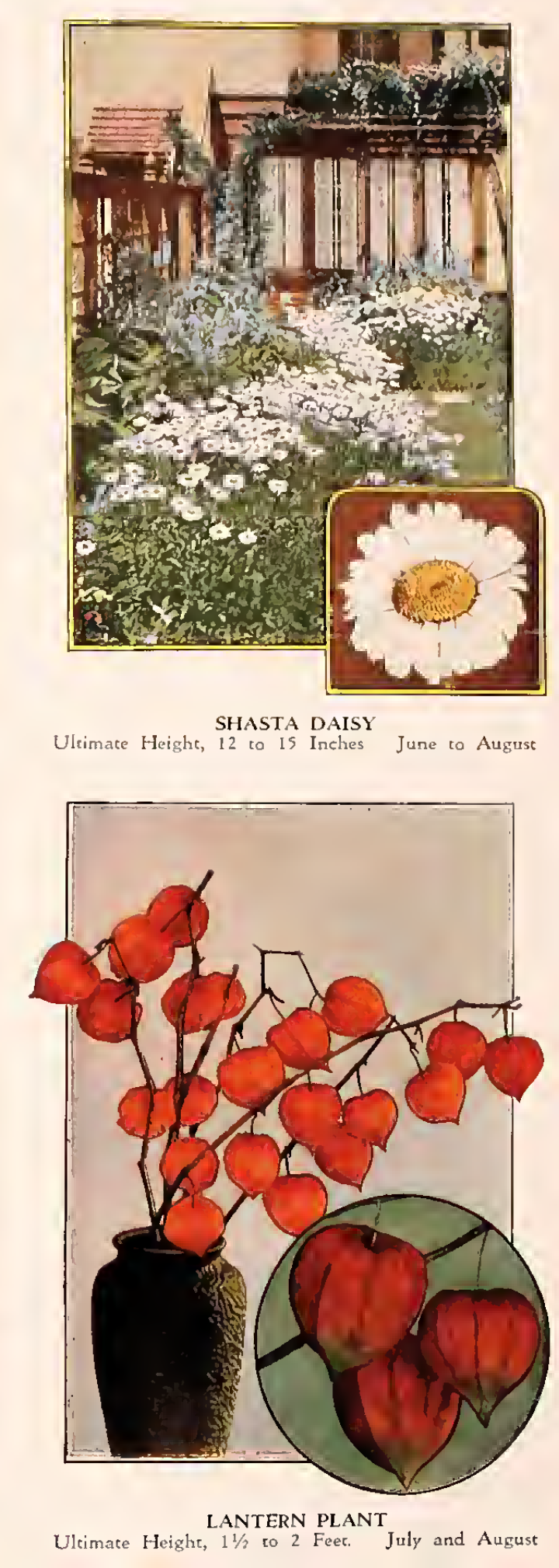



\section{Planting Plans}

\section{For Old-Fashioned Perennials}

Be sure to plant only healthy, vigorous stock, the only kind that will thrive with very little attention.

With their variety of form and riot of color, no other class of plants yield such beauty and fragrance at so low a cost with so little care, and none can be used in so many varied locations.

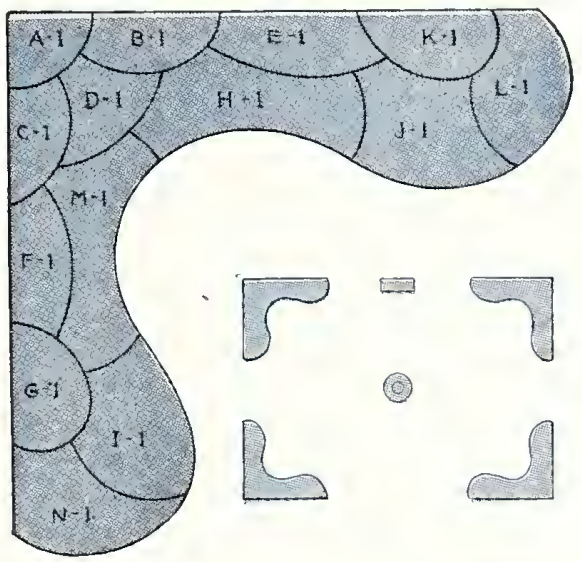

PLAN No. 1

6 feet $\times 6$ feet

\section{PLAN No. 1}

$\begin{aligned} \text { (14 } & \text { Perennials) } \\ \text { A-1 } & \text { Hollyhock } \\ \text { B-1 } & \text { Delphinium } \\ \text { C-1 } & \text { Foxglove } \\ \text { D-1 } & \text { Coreopsis } \\ \text { E-1 } & \text { Phlox } \\ \text { F-1 } & \text { Tritoma } \\ \text { G-1 } & \text { Lantern Plant } \\ \text { H-1 } & \text { Shasta Daisy } \\ \text { I-1 } & \text { Columbine } \\ \text { J-1 } & \text { Sweet William } \\ \text { K-1 } & \text { Yucca } \\ \text { L-1 } & \text { German Iris } \\ \text { M-1 } & \text { Gaillardia } \\ \text { N-1 } & \text { German Iris }\end{aligned}$

For an individual corner planting or in pairs on 4 sides of the garden

\section{PLAN No. 2}

$$
\begin{aligned}
\text { (30 } & \text { Perennials) } \\
\text { A-2 } & \text { Coreopsis } \\
\text { B-2 } & \text { Chinese Lantern Plant } \\
\text { C-2 } & \text { German Iris-Bronze } \\
\text { D-2 } & \text { Sweet William } \\
\text { E-2 } & \text { Yucca } \\
\text { F-4 } & \text { Columbine } \\
\text { G-2 } & \text { Tritoma } \\
\text { H-2 } & \text { Hollyhock } \\
\text { I-2 } & \text { Delphinium } \\
\text { J-2 } & \text { Shasta Daisy } \\
\text { K-2 } & \text { Foxglove } \\
\text { L-2 } & \text { Phlox } \\
\text { M-2 } & \text { Gaillardia } \\
\text { N-2 } & \text { German Iris }
\end{aligned}
$$
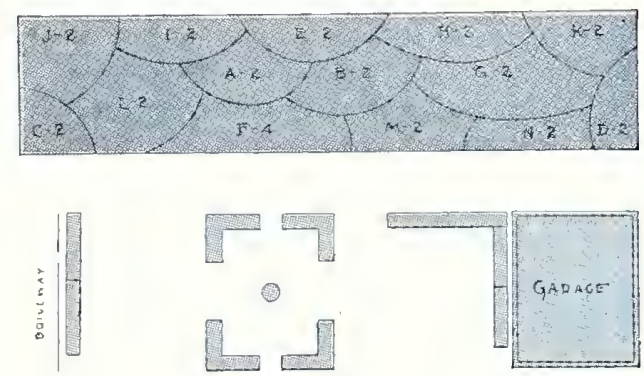

PLAN No. 2

9 feet $\times 2$ feet

Suggesting three combinations using Plan No. 2

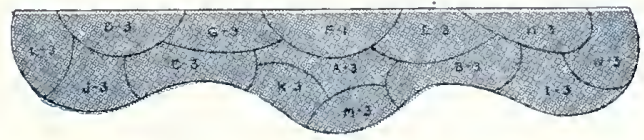

$\{\cdots$

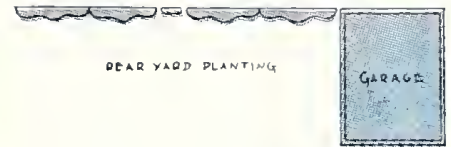

PLAN No. 3

12 feet $\times 2$ feet overall

\section{PLAN No. 3}

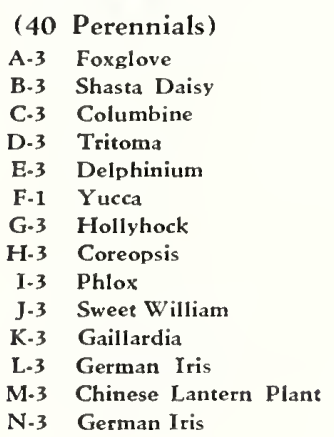

The list of plants under the above offers provide material for a single bed of the size and shape illustrated. If additional beds are planned order as many groups of plants as required. 


\section{The Old-Fashioned Garden}

Makes the Home Grounds Beautiful

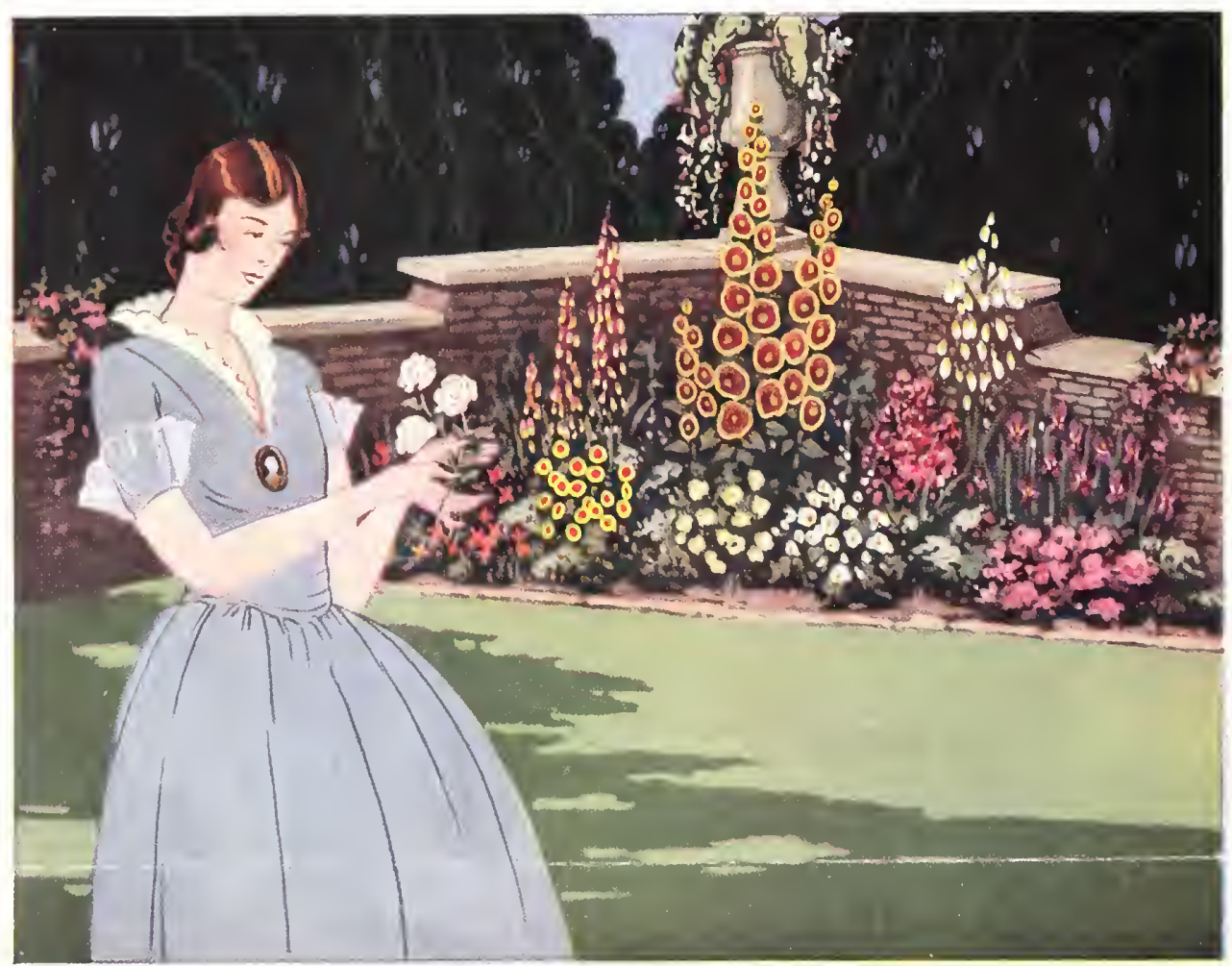

Perennials improve greatly after the first year, as the roots grow stronger. This picture gives a good idea of the colorful display of a perennial bed arranged according to Plan No. 1.

\section{YOUR FLOWER GARDEN}

Everyone needs an old-fashioned perennial garden. No matter how completely a home is landscaped, there is always a place for perennials.

This special perennial group should provide flowers all season in a variety of colors and blossoms that cannot be excelled.

If you want flowers to cut and make your home grounds beautiful, you should have this choice col. lection of perennials.

\section{Special Prices on Perennials}

\begin{tabular}{|c|c|c|c|}
\hline (c)lun11line & 10 for $\$ 1.00$ & Harely licrus & 6) for $\$ 1.00$ \\
\hline larkspur & 10 for $\$ 1.00$ & llollyheck & $10 f(0) \$ 1.00$ \\
\hline Hepatica & 10 for $\$ 1.00$ & Corenpuse & (6) for $\$ 1.00$ \\
\hline llarely I'lnlox & 10 for $\$ 1.00$ & Tritoma & + for $\$ 1.00$ \\
\hline Lemon Lilies & $\&$ for $\$ 1.00$ & Sliasta Maisy & + for $\$ 1.00$ \\
\hline 1.iatris & 10 [or $\$ 1.00$ & Sweet William & $+f(x \$ 1.00$ \\
\hline Mertentia & $12 f(0) \$ 1.00$ & Gaillarelia & + for $\$ 1.00$ \\
\hline Herperis & $10 \mathrm{for} \$ 1.00$ & lincea & $+f o r \$ 1.00$ \\
\hline
\end{tabular}

